\title{
STEPPING STONES TO A DEGREE: THE IMPACT OF ENROLLMENT PATHWAYS AND MILESTONES ON COMMUNITY COLLEGE STUDENT OUTCOMES
}

\author{
Juan Carlos Calcagno, Peter Crosta, Thomas Bailey, and Davis Jenkins
}

October 2006

\section{CCRC Working Paper No. 4}

\author{
Address Correspondence to: \\ Juan Carlos Calcagno \\ Community College Research Center \\ Teachers College, Columbia University \\ 525 W. $120^{\text {th }}$ Street, Box 174 \\ New York, NY 10027 \\ Tel.: (212) 678-3874 \\ Fax: (212) 678-3699 \\ Email: jcc2111@columbia.edu
}

This research was funded through a research grant from the Association for Institutional Research and National Postsecondary Education Cooperative. Additional support was provided by Lumina Foundation for Education as part of the Achieving the Dream: Community Colleges Count initiative. An earlier version of this paper was presented at the 2005 American Educational Research Association and the 2006 Association for Institutional Research annual meetings. We thank Greg Kienzl, Linda Hagedorn, and Wendy Schwartz for detailed comments and suggestions that have improved the paper. We are grateful to Pat Windham and Judith Thompson of the Florida Department of Education for sharing the data and providing insights to help explain the findings. 


\begin{abstract}
This paper presents findings from a study of the experiences and outcomes of older and younger community college students. We developed a discrete-time hazard model using longitudinal transcript data on a cohort of first-time community college students in Florida to compare the impact of enrollment pathways (such as remediation) and enrollment milestones (such as attaining a certain number of credits) on educational outcomes of older students — those who entered college for the first time at age 25 or later-with those of traditional-age students. Results suggest that reaching milestones such as obtaining 20 credits or completing 50 percent of a program is a more important positive factor affecting graduation probabilities for younger students than it is for older students. We also found that although enrollment in remedial courses decreases the odds of graduating for all students, older students who enroll in remediation are less negatively affected than are younger ones who do the same.
\end{abstract}




\section{Table of Contents}

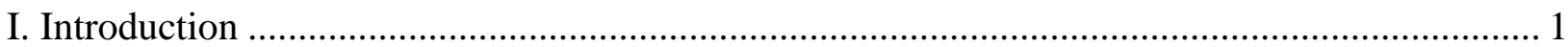





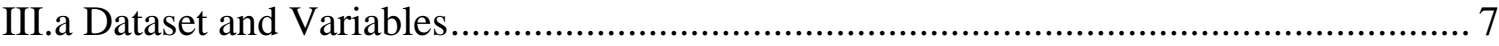

III.b Empirical Methodology and Data Arrangement.................................................. 14

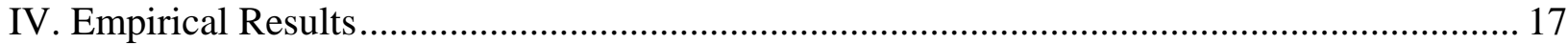

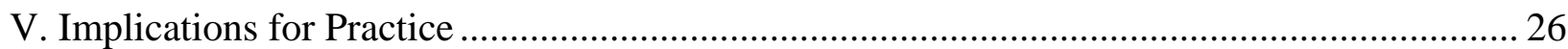

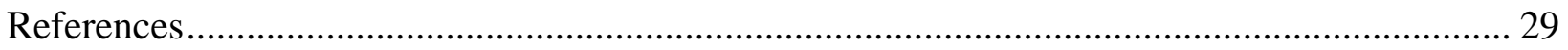




\section{Introduction}

Community colleges are an important entry point to postsecondary education for adults with no previous college education (Cohen \& Brawer, 1996). In fall 2002, adults between age 25 and 64 represented 35 percent of full-time-equivalent (FTE) enrollments at two-year public colleges, compared with only 15 percent of FTE undergraduate enrollments at four-year public institutions (U.S. Department of Education, 2003). While enrolled, older students are more likely than younger students to be working, married, caring for children, and less engaged with traditional-age students in the college (Choy \& Premo, 1995; Horn \& Carroll, 1996). They are also more likely to attend part time, to enroll in an occupational rather than an academic program, and to seek an occupational certificate rather than pursue an associate degree or transfer to a four-year institution (Bailey et al., 2003). Not surprisingly, Adelman contends that “one demographic variable makes an enormous difference in the distribution of virtually any postsecondary outcome or process—age at the time of first entry to postsecondary education” (Adelman, 2005, pp. 119).

The factors associated with older students can certainly affect enrollment patterns, enrollment intensity, and the probability of completing a degree (Choy, 2002a). In fact, based on data from the Beginning Postsecondary Students Longitudinal Study, we found that 60 percent of older first-time community college students, compared with 40 percent of younger first-time students, did not earn any credential or transfer after six years. This gap in graduation and transfer rate probabilities could be better understood if we recognized how enrollment pathways (such as remediation) and enrollment milestones (or intermediate outcomes) affect these 
educational outcomes and whether they affect older and younger students differently. For example, enrollment patterns and intensity can determine when students reach an educational milestone, such as earning a certain number of credits or finishing a certain percentage of their program (McCormick, 1999). Whether and when an older student achieves various educational milestones can have an impact on her graduation probability, whereas milestone achievement does not have the same effect for younger students. In addition, enrollment in remedial classes is an educational pathway that may also have a different impact on the probability of attaining a positive outcome for older and younger students, and, indeed, close to 60 percent of the first-time community college students in the National Education Longitudinal Study 1988-2000 took at least one remedial course. ${ }^{1}$

In this study, we used longitudinal unit record transcript data on a cohort of first-time community college students in Florida to determine whether enrollment pathways and milestones had the same impact on the conditional probability of graduating for older students as they did for younger students. Besides providing insight into an important group of community college students, this study presents a model for analyzing student enrollment patterns and milestones using longitudinal unit record data. The remainder of the paper is organized as follows: The next section presents basic background about the topic and a literature review. Section III describes the Florida data and presents the theoretical foundations for the model. Section IV provides results from our single risk discrete-time hazard models, and Section V presents our conclusions, including implications for practice.

\footnotetext{
${ }^{1}$ Authors' calculations from National Education Longitudinal Study 1988-2000.
} 


\section{Review of the Literature}

College completion and dropout rates have long been a central preoccupation of research on higher education. The general consensus among educators and researchers is that students who have stronger high school records, who come from higher income families, whose parents also went to college, who do not delay college entry after high school, who attend full time and receive some form of aid, and who do not interrupt their college studies are more likely to graduate. The most widely used conceptual frameworks of persistence and completion developed by education researchers are based on Tinto’s Student Integration Model (1993) and Bean’s Student Attrition Model (1985). The central implication of their models is that institutions should try to foster the academic and social engagement of their students in and with the college in order to maximize persistence and retention rates. ${ }^{2}$ Bean and Metzner (1985) provide a theoretical framework maintaining that nontraditional students (older, part-time, and commuter students) are more negatively affected by environmental factors than they are positively affected by social and academic integration, and, therefore, they are more likely to interrupt and drop out than are traditional students.

There is a growing empirical literature on student pathways into and through higher education that uses Tinto’s and Bean’s models as theoretical frameworks. Some studies have examined the movement of students across educational sectors—high school to college, community college to baccalaureate, etc.—-whereas others have looked at retention within particular levels of higher education, and still others have done both (e.g., Adelman, 2006; Cabrera, Burkum, \& La Nasa, 2005; Choy, 2002b). What these studies have in common is that they track cohorts of students over time, examine the "critical filter points” where students drop

\footnotetext{
${ }^{2}$ These models have generated a large amount of research that has been thoroughly summarized by Pascarella and Terenzini (2005).
} 
out, and seek to understand the determinants of success both for students generally and for particular groups. This work has been facilitated by the availability of longitudinal datasets such as High School and Beyond (HS\&B), National Education Longitudinal Study (NELS), and Beginning Postsecondary Students Longitudinal Study (BPS).

An influential part of this literature has tied achieving credit milestones to earning credentials. One study by the National Center for Education Statistics (NCES) (McCormick, 1999) focused on credit attainment as an intermediate outcome for students seeking a bachelor's degree. The author argued that credit accumulation provides a basic measure of progress through postsecondary education and offered information on enrollment intensity, persistence, retention, success, and time-to-degree. The researcher used HS\&B 1980-1993 data to find that four-year students who completed at least 20 credits in their first year averaged about 86 credits overall. Completing 30 credits in the first year boosted the average to 128 credits overall. Linking these findings to bachelor's degree completion, 45 percent of those with fewer than 20 credits in year one (but more than 10) completed that degree, while 91 percent of those who earned 30 credits in the first year completed a bachelor's.

Moreover, consistently throughout other studies published by NCES, community college students who earned fewer than 10 college credits were removed from the samples analyzed (Adelman, 1999, 2004, 2005, 2006). These students were called "incidental students" and considered to be not committed to pursuing a postsecondary credential. Implicit here is the notion that earning at least 10 college credits—reaching this educational milestone-is an intermediate outcome that substantially impacts the probability of graduation or transfer. There is no literature, however, that focuses on the differential impact of credit attainment on older and younger students. 
Similarly, research results on remediation suggest that such study is merited. Researchers have argued that passing gatekeeper classes, such as remedial and initial college-level courses, can substantially increase the probability of earning a secondary credential (Adelman, 2006; Bailey \& Alfonso, 2005). In particular, remediation or developmental education is a necessary part of the enrollment path for many community college students. Research on remediation, although focusing largely on remediation at four-year schools, suggests that students who enroll in developmental courses graduate at lower rates than those who start in regular credit courses (Bailey \& Alfonso, 2005). Low reading skills are also seen as a significant barrier to completion, as students need extensive remediation of reading and writing skills. In addition, it has been shown that the more remedial courses a student is required to take, the less likely the student is to earn a degree (Adelman 1999). It is interesting to note that recent contrasting research on California community colleges found that remedial classes are positively associated with secondterm retention in college and completion of a transfer-level class (Jepsen, 2006). Moreover, when the author isolated the effect for younger and older students, he found that remedial classes were negatively related to the probability of transferring for younger students, whereas for older students the classes were positively related to that probability or to the receipt of a degree or certificate. The later results suggest differential effects for younger and older students.

As noted above, many studies use longitudinal data to estimate the probability of completing college. However, most of these studies look only at two points in time. First, when students start their postsecondary education, researchers collect a set of relevant covariates presumably associated with completion rates, like gender, race/ethnicity, socioeconomic status (SES), test scores, and institutional characteristics. After a given amount of time has passed to allow students to graduate, researchers again collect data to estimate the direct effect of these 
factors on some combination of policy-relevant educational outcomes, such as graduation, dropout, persistence, or transfer. This strategy masks fundamental variation that could explain degree completion because factors such as enrollment patterns are likely to change over time. Event history modeling, or survival analysis, is specifically designed to study the occurrence and timing of events (Allison, 1984; Singer \& Willett, 2003) and thus is appropriate for handling the dynamic nature of the higher education process (DesJardins, 2003). By using information that is revealed during the educational process, event history models allow researchers to dynamically measure the impacts of intermediate outcomes and enrollment pathways on some final outcome. Although not prevalent in the higher education literature, and almost absent from community college research, the method has been used in a number of studies to model dropout and completion among college students (DesJardins, Ahlburg, \& McCall, 1999; Ishitani, 2003; Johnson, 2006; Scott \& Kennedy, 2005). None of these studies, however, used the method to examine how remediation and other course-taking patterns and intermediate outcomes, such as credit attainment, affect the final educational outcomes of community college students.

This paper contributes to the literature by applying the event history method to the study of the impact of enrollment pathways and milestones on student success among community college students. The question we sought to answer is whether remedial pathways and intermediate outcomes (milestones) have the same impact on the conditional probability of graduating for older students as they do for younger students. Specifically, we aimed to determine: (1) how the attainment of certain educational milestones affects the probability of graduation for older community college students compared with traditional-age students at community colleges, (2) to what extent enrollment in developmental education is a barrier to completion for older students compared with younger students, and (3) how the timing of 
completing of the first college-level math or writing class affects the probability of graduation for older and younger students who have enrolled in developmental education courses.

\section{Data and Empirical Model}

\section{III.a Dataset and Variables}

This study draws on unit record data on 42,641 first-time, degree-seeking Florida college students who enrolled in a college-credit course at one of Florida's 28 community colleges in the fall of the 1998-1999 academic year. The dataset tracks enrollment by students at Florida community colleges through spring 2004 (17 trimesters, where a trimester is a fall, spring, or summer term). It includes information on the demographic characteristics of all entering students, including age, gender, race/ethnicity, previous education, and college placement test scores. It also includes basic transcript information with credits attempted and completed by term, full- or part-time enrollment status, program of study, credentials earned, and amount and type of financial aid received in the first semester.

We removed any students who were formerly in dual high school/college enrollment programs and were now out of high school and officially in college. We also restricted the sample to students who were between age 17 and 65 on September 1 of their first term of college (fall 1998). Finally, we limited the younger student group to those who entered college between age 17 and 20, while the older group remained those students who entered between age 25 and 65. ${ }^{3}$ This restriction addresses the fact that students who begin at age 23 , for example, would technically be older students by their third year of study. Therefore, our analysis compares students who enrolled at a traditional age and remained traditional-age students for 15 of the 17 trimesters with students who enrolled at an older age and remained nontraditional-age students

\footnotetext{
${ }^{3}$ We lost 3,619 observations with this restriction.
} 
for the entire span of data collection. All of these modifications resulted in a sample of 29,421 traditional-age students and 5,652 older students.

Table 1 summarizes the variables that we used in the analysis. The group of older students in the cohort had a larger proportion of female students, a larger proportion of Black and White students, and a smaller proportion of Hispanic students than did the younger group. Most striking are the differences between a student's receipt of a high school diploma or a GED: older students were more likely to have received a nontraditional secondary credential. There are interesting differences in the math and verbal test scores of older and younger students as well. ${ }^{4}$ Traditional-age college students, on average, scored about 87 points higher than older students on mathematics placement exams, but they scored about 29 points lower on tests of verbal skills. This discrepancy could result from older students’ being away from formal mathematics education for an extended period of time, whereas their verbal scores may have improved over time since vocabulary and language skills are used in work and everyday life.

\footnotetext{
${ }^{4}$ Students report SAT or ACT test scores upon enrollment, and if they did not take these tests, they must take a college placement test at their institution. Scores for placement tests were all converted to an SAT scale (200-800) using the test makers' formulas.
} 
Table 1: Characteristics of First Trimester Students

\begin{tabular}{|c|c|c|c|}
\hline Characteristic & Younger & Older & Difference \\
\hline Female & $52.38 \%$ & $59.34 \%$ & $-6.96 *$ \\
\hline Age & $18.25 \%$ & $33.93 \%$ & $-15.68 *$ \\
\hline \multicolumn{4}{|l|}{ Race/Ethnicity } \\
\hline Black & $16.59 \%$ & $18.84 \%$ & $-2.25^{*}$ \\
\hline Asian or Pacific Islander & $2.86 \%$ & $2.25 \%$ & $0.61 *$ \\
\hline Hispanic & $19.25 \%$ & $15.82 \%$ & $3.43 *$ \\
\hline American Indian & $0.46 \%$ & $0.65 \%$ & -0.19 \\
\hline White & $60.48 \%$ & $62.31 \%$ & $-1.84 *$ \\
\hline Unknown Race/Ethnicity & $0.36 \%$ & $0.12 \%$ & $0.24 *$ \\
\hline U.S. Citizen & $88.79 \%$ & $82.61 \%$ & $6.18 *$ \\
\hline \multicolumn{4}{|l|}{ High School Credential } \\
\hline HS Diploma & $85.67 \%$ & $68.00 \%$ & $17.67 *$ \\
\hline GED & $6.06 \%$ & $26.85 \%$ & $-20.78 *$ \\
\hline Other HS Credential & $0.57 \%$ & $0.09 \%$ & $0.48 *$ \\
\hline \multicolumn{4}{|l|}{ Placement Test Scores (200-800 scale) } \\
\hline Mathematics & 415.17 & 327.68 & $87.50^{*}$ \\
\hline Verbal & 447.38 & 476.00 & $-28.62 *$ \\
\hline Received Federal Aid in Term 1 & $26.73 \%$ & $35.93 \%$ & $-9.20 *$ \\
\hline Tuition in Term 1 & 1309.68 & 1316.47 & $-6.79 *$ \\
\hline Full-time Term 1 & $65.55 \%$ & $31.00 \%$ & $34.55^{*}$ \\
\hline Program Length in Term 1 (credits) & 60.38 & 58.88 & $1.50 *$ \\
\hline Number of Observations $^{\dagger}$ & 29,421 & 5,652 & \\
\hline
\end{tabular}

As the first term of college is decidedly important, Table 1 also presents a set of student characteristics in the first trimester of college enrollment. ${ }^{5}$ We first note that older students were more likely to receive federal financial aid. Perhaps they were better informed about their financial aid eligibility and application processes than were younger students, which may have given them an advantage in gaining financial assistance. Although community college students of all ages often hold full-time jobs while they attend school, the finding that older students were

\footnotetext{
${ }^{5}$ As defined in Table 1, these variables are time-invariant, restricted to the first trimester of college. However, tuition, full-time status, and program length are allowed to vary over time in our model.
} 
significantly more often part-time students seems reasonable since older students are more likely to have greater career, financial, and family obligations. We expected that older students would be more likely than younger students to enroll in community college to upgrade their jobs skills, resulting in the older group having a disproportionate number of students enrolled in certificate programs of shorter duration than in academic transfer programs. Table 1 indicates that the difference in average program length between the groups is slightly positive, suggesting that older students are well represented in associate degree programs despite our expectation.

The last set of variables used in our analysis concerns enrollment pathways, milestones, and outcomes. The first row on Table 2 shows the main outcome event that we considered: completion. Completion is defined as receiving a degree or certificate in one of the 17 trimesters of the event period. Those who did not complete a degree in the time period and but were still enrolled were "right censored" in their last enrollment term. As seen in Table 2, traditional-age students were, on average, more likely than were older students to graduate in 17 terms. 
Table 2: Enrollment Pathway, Milestone, and Outcome Descriptive Statistics

\begin{tabular}{|c|c|c|c|}
\hline \multirow{2}{*}{$\begin{array}{l}\text { Enrollment Pathway, Milestone, or } \\
\text { Outcome }\end{array}$} & \multicolumn{3}{|c|}{ Percentages by age group } \\
\hline & Younger & Older & Difference \\
\hline \multicolumn{4}{|l|}{ Outcome } \\
\hline Completion in 17 terms & 29.92 & 19.04 & $10.88^{*}$ \\
\hline \multicolumn{4}{|l|}{ Nominal Credit Milestones } \\
\hline Earned 10 credits & 78.71 & 61.50 & $17.21 *$ \\
\hline Earned 10 non-remedial credits & 70.98 & 53.72 & $17.27 *$ \\
\hline Earned 20 credits & 65.47 & 44.55 & $20.92 *$ \\
\hline Earned 20 non-remedial credits & 59.13 & 39.61 & $19.52 *$ \\
\hline \multicolumn{4}{|l|}{ Percentage of Program Completion } \\
\hline \multicolumn{4}{|l|}{ Milestones } \\
\hline Finished $5 \%$ of program & 88.11 & 80.91 & $7.20 *$ \\
\hline Finished $15 \%$ of program & 77.17 & 65.55 & $11.61^{*}$ \\
\hline Finished $25 \%$ of program & 69.12 & 56.74 & $12.38 *$ \\
\hline Finished $50 \%$ of program & 55.46 & 43.97 & $11.49 *$ \\
\hline Finished $75 \%$ of program & 46.70 & 36.75 & $9.95 *$ \\
\hline \multicolumn{4}{|l|}{ Remedial Pathways } \\
\hline Enrolled in Remediation & 61.43 & 60.19 & 1.24 \\
\hline Mathematics & 48.82 & 51.61 & $-2.79 *$ \\
\hline Reading & 34.27 & 21.07 & $13.20^{*}$ \\
\hline Writing & 29.38 & 20.47 & $8.91^{*}$ \\
\hline \multicolumn{4}{|l|}{$\begin{array}{l}\text { Passed First College-Level Course } \\
\text { Milestones }^{\dagger}\end{array}$} \\
\hline Writing & 52.58 & 38.81 & $13.77 *$ \\
\hline Mathematics & 25.12 & 17.14 & $7.98 *$ \\
\hline Number of Observations & 29,421 & 5,652 & \\
\hline
\end{tabular}

Our model includes several time-varying indicators for the enrollment pathways and milestones, which are the model's main focus. They can be classified into four categories: nominal credit milestones, percentage of program completion milestones, remedial pathways, and milestones of passing the first college-level writing and mathematics courses. The first set of milestones identifies when a student completes 10 or 20 credits, following Adelman’s (2004) 
assertion that a major milestone in undergraduate education is the attainment of 10 credits. In our sample, 62 percent of older and 79 percent of younger students obtained at least 10 credits during the observation period. If we exclude remedial credits from this measure, 54 percent of older and 71 percent of younger students attained at least 10 non-remedial credits during the observation period. The disparities noted here may be due to differences in enrollment intensity; older students may be more likely to enroll part time and therefore have a more difficult time accumulating credits. Similarly, a greater proportion of younger students, on average, reached the 20-credit milestone, whether counting all credits or only non-remedial credits.

If older students are overrepresented in programs requiring fewer credits, then credit accumulation differences may not be very meaningful. Therefore, we suggest an alternate way to gauge student progress: percentage of program completed. This is simply the proportion of nonremedial credits earned relative to the number of credits required for a given student's program. We considered five milestones for program completion at 5, 15, 25, 50, and 75 percent. Presumably students who completed increasing amounts of their program would have much better odds of graduating and lower odds of dropping out. There may also be percentage milestones that are particularly important or that have different impacts for our two groups. On all five measures, older students completed a lower percentage of their programs than did younger students.

Remedial pathways were tested using four different variables, each testing time-invariant impacts of enrolling in remedial courses. The measures indicate whether or not a student enrolled in developmental classes in general, and if she enrolled in math, reading, or writing developmental education courses specifically. In our sample, there was little difference between older and younger students in the percentage of students enrolled in remedial classes: about 60 
percent each. However, older students were more likely to enroll in mathematics remediation and much less likely to enroll in reading or writing remediation than their younger counterparts.

Another milestone worth analyzing for students enrolled in mathematics or writing remediation is passing the first college-level course in those subjects. We were interested in seeing whether and when a remedial student completes her first college-level mathematics and writing courses, and how doing so affects her probability of graduation. The first mathematics course is college algebra, and a higher percentage of younger students who took remedial math took and passed this class than did older students. The writing course is the standard first-year composition course. About 53 percent of younger and 39 percent of older students who enrolled in remedial writing passed this course in the observation period.

Our list of explanatory variables has some key omissions that should be noted. As discussed, studies of completion rates show, not surprisingly, that students who come from higher income families and whose parents also went to college have a higher probability of graduation (Adelman, 1999, 2005, 2006; Bailey \& Alfonso, 2005; Cabrera et al., 2005). The Florida unit record dataset does not include information on either of these socioeconomic (SES) characteristics of students, but our study used two strategies to overcome this limitation. ${ }^{6}$ First, we added an indicator variable for students receiving federal aid. This measure, which primarily comprises Pell Grants awarded to low- and middle-income students, acts as a proxy for the relative income level of students. Second, we included comprehensive information on test scores and we assumed these variables to be highly correlated with unobserved SES. ${ }^{7}$ To the extent that

\footnotetext{
${ }^{6}$ The effect of unobserved heterogeneity is thoroughly analyzed in a complementary paper by the same authors. The results do not change any of the conclusions in this analysis.

7 See Rothstein (2004) or Cameron \& Heckman (1998) for supporting evidence.
} 
long-term family and environmental factors are reflected in measures of scholastic ability, we accurately controlled for SES. ${ }^{8}$

\section{III.b Empirical Methodology and Data Arrangement}

The event history statistical method we used to model outcomes of community college students is the single risk discrete-time hazard model (Allison, 1984; DesJardins, 2003; Singer \& Willett, 2003). To facilitate discussion of this model, it is useful to first describe how the dataset is organized. Rather than one observation per student, we use a person-period dataset with a maximum of 17 observations per student: one for each trimester, with each student observed only upon enrollment in that term. Time-invariant variables remained constant for each person in each period, and time-varying variables could take on different values in different time periods. Our event is completion of a degree from a community college in Florida, and in our framework we considered that each student was "at risk" of completing when first enrolled. Once a student experienced an event, her observations in later time periods were discarded, effectively preventing her from reentering the risk set. Since we had 17 trimesters of data (five years plus two trimesters), we could only observe outcomes for these 17 terms, and the 17 terms are referred to as the "event time" or "event period." The beginning of event time was the first term of enrollment in a Florida community college (fall 1998) and the end was spring 2004. Students

\footnotetext{
${ }^{8}$ Noticeably absent from this discussion is transfer as an outcome. Those students who failed to obtain a degree or certificate but did transfer out of the Florida Community College System — whether to another state's two-year college or to a private or public four-year college-would be right censored observations; we did not know what happened to them. Using the limited data available on transfers to the State University System, we estimated a competing risk model with transfer and degree completion as outcomes. The results (not shown here but available upon request) do not change any of the conclusions in this analysis and confirm that a single risk model is adequate.
} 
who had not completed by the seventeenth term had unknown outcomes at the end of the event period and thereafter. ${ }^{9}$

Formally, we were modeling the risk of completion in each trimester, called the hazard. This is the conditional probability that an individual would obtain an outcome in time period $j$, given that she did not do so in an earlier time period and given that she was in the risk set. To be in the risk set in a given trimester, the student must be enrolled. The general population discretetime hazard can be conceptualized as:

$$
h\left(t_{j}\right)=\operatorname{Pr}\left[C_{k}=j \mid C_{k} \geq j, G, \mathbf{X}, \mathbf{Z}\right]
$$

where $C_{k}=j$ indicates student $k$ 's outcome in term $j$, $\mathrm{G}$ is an indicator variable for being an older student, $\mathbf{X}$ is a vector of students characteristics, and $\mathbf{Z}$ is a vector of intermediate outcomes or milestones. The condition $C_{k} \geq j$ ensures that an outcome for student $k$ has not occurred before time period $j$ and that the student is enrolled in (observed in) time period $j$. The hazard in this case was the conditional probability that student $k$ completes in term $j$ given that she did not complete before $j$ and was in the risk set. The occurrence of these milestone events raises or lowers the hazard of the final outcome; hence we could enter them in the model as time-varying explanatory variables (Allison, 1984). Algebraically, we can write this relationship as:

$$
\operatorname{logit} \mathrm{h}\left(\mathrm{t}_{\mathrm{j}}\right)=\mathbf{D}_{\mathrm{j}}^{\prime} \alpha_{\mathrm{j}}+\mathrm{G}^{\prime} \delta+\mathbf{X}^{\prime} \beta+\mathbf{Z}^{\prime} \gamma
$$

In equation (2), we took the logit of the hazard ${ }^{10}$ and defined a linear relationship between the conditioning data and logit hazard, where $\mathbf{D}_{\mathrm{j}}$ is a vector of dummy variables

\footnotetext{
${ }^{9}$ In order to produce unbiased analyses, we must assume that the censoring due to the end of event time or due to non-enrollment is non-informative with respect to event occurrence, or, in other words, students were actually still capable of graduating (Singer \& Willett, 2003).

${ }^{10}$ A discrete-time hazard model using a logit transformation assumes proportional odds rather than proportional hazards. See Singer and Willett (2003, chap. 12).
} 
indexing each trimester; and $\alpha, \delta, \beta$ and $\gamma$ are parameters to be estimated. Taking an inverse transformation of both sides, we derive:

$$
h\left(t_{j}\right)=\frac{1}{1+e^{-\left[\mathbf{D}_{j^{\prime} \alpha_{j}+G^{\prime} \delta+\mathbf{X}^{\prime} \beta+\mathbf{Z}^{\prime} \gamma}\right]}}
$$

which is now a nonlinear relationship between the predictors and the hazard and analogous to the standard logistic regression routine (Singer $\&$ Willett, 2003). Once the data were put in a personperiod dataset, we could estimate parameters that maximized the likelihood of observing the sample data assuming a logistic distribution.

Since event history analysis has a large temporal component, it is important to discuss our treatment of time in the equations presented above. Our discrete-time models assumed a general non-parametric specification for time that is entered as a series of $t$ dummy variables indicating each trimester as $\mathbf{D}_{\mathrm{j}} \alpha_{\mathrm{j}}$. That is, no explicit functional restrictions were placed on how time affects the probability of completion. This allowed the baseline hazard to take on any shape and thus captured the effect of enrollment patterns through time, or the profile of hazard over time. Moreover, empirical evidence suggests that the misspecification problems due to unobserved heterogeneity that is uncorrelated with observed covariates are reduced when researchers use a fully-flexible non-parametric duration dependence (Dolton \& van der Klaauw, 1995). In this case, any unobservable factor affecting enrollment patterns would be captured by the time fixed effects. Often, researchers can justify entering the time component into the model as a linear, quadratic, or cubic function of time, for example, due to an observed relationship with the hazard event and to reduce degrees of freedom used in the analysis. However, the sample size of our dataset allowed us to add 17 new parameters (one for each time period) to 
estimate without compromising the reliability of results. Moreover, after some experimentation, we determined that the general specification is the best fit for our data. ${ }^{11}$

\section{Empirical Results}

We further estimated several hazard models to test whether milestone attainment, remediation, and passing first college-level math and writing classes had a different impact on the probability that older and younger students would graduate. We approached hazard modeling — estimating equations in the form of equation (3) — by first beginning with a simple model that included only the effects of time and the older student dummy variable. Then covariates were introduced into the model to compare the older and younger groups. This step was followed by the entering of our intermediate outcomes (or milestones) as both time-varying and time-invariant predictors (Allison, 1984).

Table 3 presents our initial odds ratios and standard errors derived from maximum likelihood estimation of logistic regression parameters. In column (1) we present a simple baseline hazard model with the time-invariant dummy variable indicating whether or not the student was in the older student group. The odds ratio of 0.925 indicates that in any given period an older (younger) student is 0.925 (1.08) times as likely as a student in the younger (older) group to complete a degree or certificate. In this model, the effects of time represent the odds of graduating in each period for a younger student. ${ }^{12}$ Figure 1 shows these results graphically.

\footnotetext{
${ }^{11}$ Model fits were determined using deviance statistics and the Akaike Information Criterion. The general nonparametric specification allowed us to capture summer spikes, as is discussed below.

${ }^{12}$ Note that because of the parameterization and logit link, the odds for the subgroups in each period are proportional with a ratio of 0.925 .
} 
Figure 1: Sample Hazard of Completion by Age

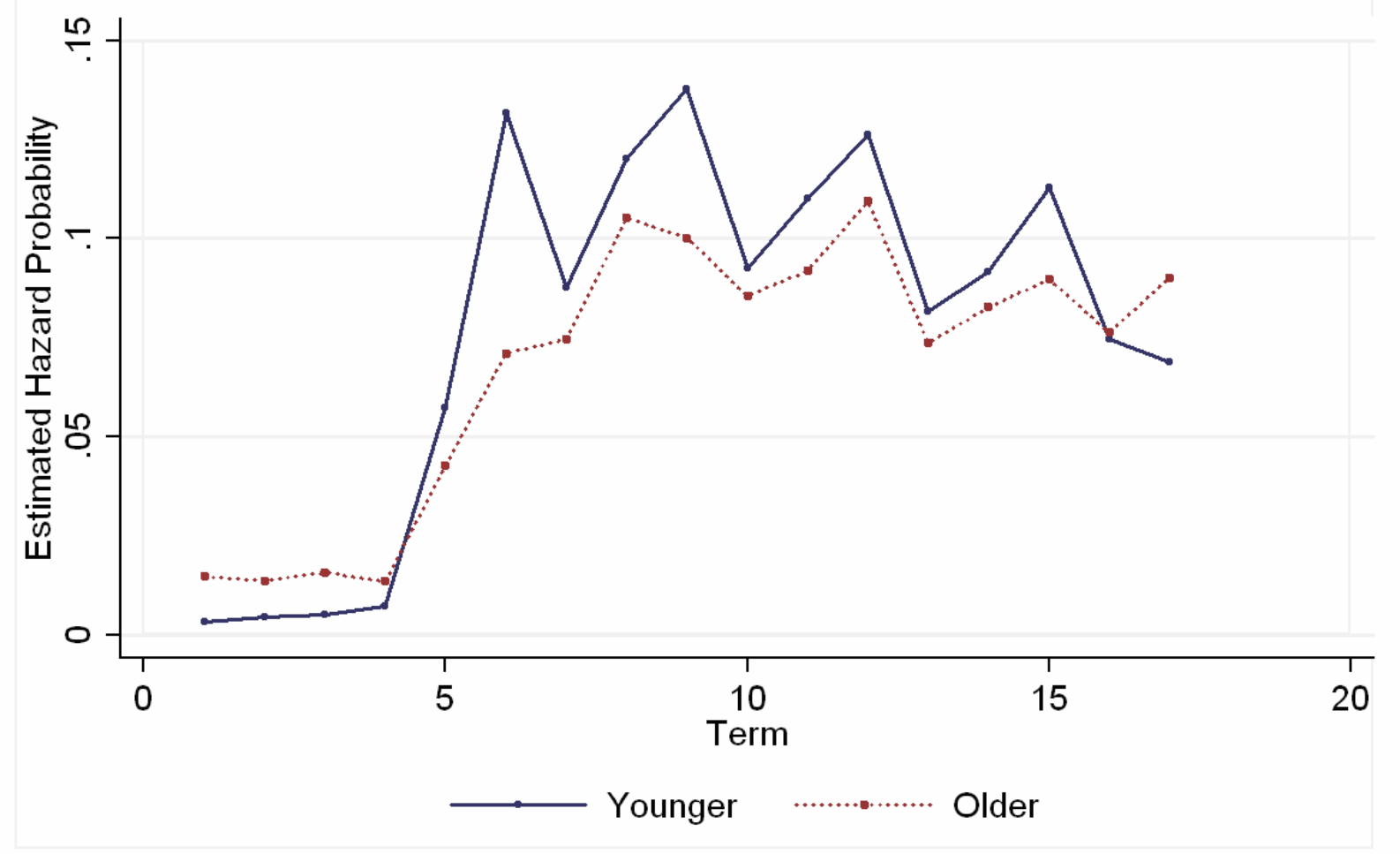

Having established an idea of baseline hazard, we added controls for sex, race/ethnicity (White is the reference group), receipt of federal aid in the first term, U.S. citizenship, secondary credential (diploma or GED), test scores, tuition, program length, and full-time status in columns (2) and (3) of Table 3. The parameter estimates again represent the covariates' effects on the conditional probability of completion in any given trimester. Column (2) suggests that students who were female and high school diploma holders were more likely to graduate in each period, whereas Blacks, American Indians, and Hispanics were less likely to complete a degree or certificate during the event period. Adding this first wave of controls pushes the effect of being 
an older student upward, so that older students were expected to be 0.94 times as likely to graduate in each time period, all other factors held constant. When we added in measures of ability and ability squared to the model (as shown in column [3]), the effect of being an older student reversed in sign. An older student was 1.24 times as likely to complete a degree as a younger student, ceteris paribus. ${ }^{13}$

Table 3: Estimated Odds Ratios for Hazard Models, with Completion as the Outcome

\begin{tabular}{|c|c|c|c|c|}
\hline Variables & $\begin{array}{l}\text { Odds (SE) } \\
\text { (1) }\end{array}$ & $\begin{array}{c}\text { Odds (SE) } \\
\text { (2) }\end{array}$ & $\begin{array}{c}\text { Odds (SE) } \\
\text { (3) }\end{array}$ & $\begin{array}{c}\text { Odds (SE) } \\
\text { (4) }\end{array}$ \\
\hline Older Student & $0.925(0.031)$ & $0.94(0.03)$ & $1.24(0.06)^{*}$ & $1.31(0.06)^{*}$ \\
\hline Female & & $1.08(0.02)^{*}$ & $1.25(0.03)^{*}$ & $1.28(0.03)^{*}$ \\
\hline Black & & $0.48(0.02)^{*}$ & $0.64(0.03)^{*}$ & $0.65(0.03) *$ \\
\hline Asian & & $0.93(0.06)$ & $0.94(0.06)$ & $0.94(0.07)$ \\
\hline Hispanic & & $0.58(0.02)^{*}$ & $0.66(0.02)^{*}$ & $0.68(0.02)^{*}$ \\
\hline American Indian & & $0.61(0.10)^{*}$ & $0.63(0.12)$ & $0.64(0.12)$ \\
\hline No Race/Ethnicity & & $0.78(0.14)$ & $0.86(0.17)$ & $0.89(0.17)$ \\
\hline U.S. Citizen & & $1.04(0.04)$ & $0.96(0.04)$ & $0.95(0.04)$ \\
\hline High School Diploma & & $1.07(0.03)^{*}$ & $1.06(0.04)$ & $1.08(0.04)^{*}$ \\
\hline Received Federal Aid in Term 1 & & $1.02(0.03)$ & $1.09(0.03)^{*}$ & $1.08(0.03)^{*}$ \\
\hline Verbal Score & & & $1.21(0.02)^{*}$ & $1.21(0.02)^{*}$ \\
\hline Verbal Score Squared & & & $0.94(0.01)^{*}$ & $0.93(0.01)^{*}$ \\
\hline Math Score & & & $1.58(0.03)^{*}$ & $1.58(0.03)^{*}$ \\
\hline Math Score Squared & & & $0.96(0.01)^{*}$ & $0.96(0.01)^{*}$ \\
\hline Tuition in Term $j$ & & & & $0.99(0.01)$ \\
\hline Full-time in Term $j$ & & & & $1.44(0.04)^{*}$ \\
\hline Program Length in Term $j$ & & & & $0.98(0.00)^{*}$ \\
\hline Number of Observations & 190,898 & 186,266 & 161,914 & 159,845 \\
\hline Number of Groups & 35,073 & 34,004 & 29,002 & 27,730 \\
\hline Deviance (-2*Log Likelihood) & 67,850 & 65,422 & 54,723 & 54,085 \\
\hline Change in Deviance $^{\dagger}$ & $-5.34^{* *}$ & $-2,428 *$ & $-10,699 *$ & $-638 *$ \\
\hline
\end{tabular}

We next analyzed the difference in older and younger student responses to enrollment milestones. Also, to test for differences in the impact of the milestone variables, we included in

\footnotetext{
${ }^{13}$ This result is discussed at length in a complementary paper by the same authors.
} 
the regression the older student indicator and the milestone variable as well as an interaction term that specifies the joint impact. This interaction term indicates whether there was a difference in the probability of graduating in any given period between the two groups. We used the coefficient on older students and the interaction term to compute the impact of the milestone that is specific to older students (Jaccard, 2001). Models for each milestone variable were estimated individually as extensions of the model in Table 3, column (4). Tables 4 and 5 report the odds ratios for the variables of interest of the individual models.

Each column in Tables 4 and 5 represents a separate regression that focuses on a specific pathway or milestone. The first row presents coefficients and standard errors for the older student dummy that indicates the effect of being an older student. The second row is the parameter estimate indicating the impact of the pathway or milestone, which is also the impact specific to younger students since we removed the impact specific to older students through an interaction term between the dummy for older students and the milestone as shown in the third row. The specific impact for older students was calculated by multiplying the odds ratios associated with the pathway or milestone (row 2) and the interaction term (row 3) and is shown in the fifth row. The bottom two rows display deviance statistics and the change in deviance that indicate improvements in the model fit compared to Table 3, column (4).

The first group of estimates concerns credit attainment. They include time-varying indicator variables that "turn on" when a student reaches the credit milestone and stay on in all periods thereafter. The first row in Table 4 reinforces our earlier claim that older students, on average, are more likely than their younger counterparts to graduate in any given period, everything else held constant. Looking at the credit milestones (row 2) we note that these odds ratios are all positive and significant and that the largest impact is associated with earning 20 
non-remedial credits. The results suggest that, on average, earning 20 non-remedial credits increased a younger student's odds of graduating in any given trimester by a factor of 7.6 over a similar younger student who had not reached this credit milestone. The interaction coefficients yield information on whether the milestone affected older and younger students differently (row 3). A term close to 1.0 indicates that there is not much of an observed difference between the two groups of students. Younger and older students seemed to respond similarly to reaching the 10credit milestone, and this was noted by statistically insignificant interaction terms.

Earning 20 credits may have had a different impact on older and younger students, however. This milestone was significantly less important for older students than for younger ones. For example, a younger student who received 20 non-remedial credits was 7.6 times as likely to graduate as a younger student who did not. An older student who received 20 nonremedial credits was only 4.9 times as likely to graduate as an older student without 20 credits. There was still a significant boost in the odds of graduating for both age groups, but the milestone had a more positive odds ratio for younger students. In fact, older students were less affected by all the credit milestones than their younger counterparts.

Although we controlled for program length, using the number of credits earned may not be the best way to measure progress. The next set of estimates in Table 4 illustrates the impact of completing certain percentages of a given program. Like the credit milestones, the odds ratio for the milestones grows as the percentage of the program completed increases. We see interaction terms for all models that are similar in magnitude to the interaction terms estimated with the credit milestones, but only the term indicating that a student finished 50 percent of her program 
Table 4: Estimated Odds Ratios for Hazard Models, Enrollment Milestones and Interactions

\begin{tabular}{|c|c|c|c|c|c|c|c|c|c|}
\hline \multirow[b]{3}{*}{ Variable } & \multicolumn{9}{|c|}{ Milestone } \\
\hline & \multicolumn{4}{|c|}{ Credits Earned } & \multicolumn{5}{|c|}{ Percentage of Program Completed } \\
\hline & $\begin{array}{l}\text { Earned } 10 \\
\text { Credits }\end{array}$ & $\begin{array}{c}\text { Earned } 10 \\
\text { Non-Remedial } \\
\text { Credits } \\
\end{array}$ & $\begin{array}{c}\text { Earned } 20 \\
\text { Credits }\end{array}$ & $\begin{array}{c}\text { Earned 20 } \\
\text { Non-Remedial } \\
\text { Credits } \\
\end{array}$ & $\begin{array}{l}\text { Finished 5\% } \\
\text { of Program }\end{array}$ & $\begin{array}{l}\text { Finished } 15 \% \\
\text { of Program }\end{array}$ & $\begin{array}{c}\text { Finished 25\% } \\
\text { of Program }\end{array}$ & $\begin{array}{c}\text { Finished } 50 \% \\
\text { of Program }\end{array}$ & $\begin{array}{l}\text { Finished } 75 \% \\
\text { of Program }\end{array}$ \\
\hline Older Student & $\begin{array}{c}2.019 \\
(0.621)^{*}\end{array}$ & $\begin{array}{c}1.746 \\
(0.418)^{*}\end{array}$ & $\begin{array}{c}2.142 \\
(0.362)^{*}\end{array}$ & $\begin{array}{c}1.938 \\
(0.292)^{*}\end{array}$ & $\begin{array}{r}2.080 \\
(0.816)\end{array}$ & $\begin{array}{c}1.947 \\
(0.481)^{*}\end{array}$ & $\begin{array}{c}1.725 \\
(0.333)^{*}\end{array}$ & $\begin{array}{c}1.684 \\
(0.246)^{*}\end{array}$ & $\begin{array}{c}1.559 \\
(0.185)^{*}\end{array}$ \\
\hline $\begin{array}{l}\text { Milestone (Impact for Younger } \\
\text { Students) }\end{array}$ & $\begin{array}{c}4.447 \\
(0.536)^{*}\end{array}$ & $\begin{array}{c}4.911 \\
(0.457)^{*}\end{array}$ & $\begin{array}{c}6.737 \\
(0.561)^{*}\end{array}$ & $\begin{array}{c}7.595 \\
(0.538)^{*}\end{array}$ & $\begin{array}{c}2.621 \\
(0.415)^{*}\end{array}$ & $\begin{array}{c}4.108 \\
(0.404)^{*}\end{array}$ & $\begin{array}{c}6.151 \\
(0.495)^{*}\end{array}$ & $\begin{array}{c}15.463 \\
(1.020)^{*}\end{array}$ & $\begin{array}{l}31.496 \\
(1.725)^{*}\end{array}$ \\
\hline Interaction (Older * Milestone) & $\begin{array}{r}0.640 \\
(0.198)\end{array}$ & $\begin{array}{r}0.730 \\
(0.177)\end{array}$ & $\begin{array}{c}0.593 \\
(0.103)^{*}\end{array}$ & $\begin{array}{c}0.645 \\
(0.100)^{*}\end{array}$ & $\begin{array}{r}0.625 \\
(0.246)\end{array}$ & $\begin{array}{r}0.655 \\
(0.163)\end{array}$ & $\begin{array}{r}0.728 \\
(0.143)\end{array}$ & $\begin{array}{c}0.743 \\
(0.112)^{*}\end{array}$ & $\begin{array}{r}0.813 \\
(0.102)\end{array}$ \\
\hline $\begin{array}{l}\text { Milestone Impact for Older } \\
\text { Students (Milestone * } \\
\text { Interaction) }\end{array}$ & 2.846 & 3.585 & 3.995 & 4.899 & 1.638 & 2.691 & 4.478 & 11.487 & 25.601 \\
\hline $\begin{array}{l}\text { Deviance } \\
\text { Change in Deviance }^{\dagger}\end{array}$ & $\begin{array}{c}53827.44 \\
257.88\end{array}$ & $\begin{array}{c}53581.82 \\
503.50\end{array}$ & $\begin{array}{c}53111.21 \\
974.11\end{array}$ & $\begin{array}{c}52530.42 \\
1554.9\end{array}$ & $\begin{array}{c}54033.33 \\
51.99\end{array}$ & $\begin{array}{c}53751.09 \\
334.23\end{array}$ & $\begin{array}{c}53183.44 \\
901.88\end{array}$ & $\begin{array}{c}50211.03 \\
3874.29\end{array}$ & $\begin{array}{l}44630.03 \\
9455.29\end{array}$ \\
\hline
\end{tabular}

* Denotes significance at 0.05 level.

${ }^{\dagger}$ Deviance tested against Table 3, column (4).

Notes: Standard errors are in parenthesis. Each column is a different regression. All models include 17 time dummies and control variables included in Table 3, column (4). 
is significantly different from zero. Here we see again that the coefficient on the milestone "finished 50 percent of program" is smaller for older students than for younger ones, though the impact is clearly positive for both. An older student who completed 50 percent of her program increased her odds of graduating in any given term by a factor of 11.5 , whereas a younger student increased her odds by a factor of 15.5 .

The measures related to remedial pathways and passing first-year writing and math course milestones are summarized next, and results are presented in Table 5. Our first remediation measures are time-invariant dummies indicating whether or not a student enrolled in any developmental education classes or, specifically, math, reading, or writing classes. As expected, students who were enrolled in remediation had a significantly lowered probability of graduating in any trimester since the student was not obtaining credit that counts toward a degree. The interaction term indicates that remediation did affect the two groups differently. Younger students who enrolled in remedial courses were 0.58 times as likely to graduate as younger students who did not enroll in college preparation courses. Older students who needed remediation changed their odds of graduating in any term by 0.77 , compared with older students who did not enroll in remediation. Thus, enrollment in remedial classes had a less negative relationship (and significantly so) to the probability of graduating for an older student than for a younger student, which corroborates results found by Jepsen (2006) for community colleges in California. This finding may reflect the varying motivations and goals of older students. Older students may not have let academic challenges deter them as much as younger students did. Also, it may be the case that older students, having been out of school longer, were more likely to need some remediation (but not a lot) because their basic skills were merely "rusty" rather than grossly deficient. 


\section{Table 5: Estimated Odds Ratios for Hazard Models, Remedial Pathways, Passing College-Level Courses Milestones, and Interactions}

\begin{tabular}{|c|c|c|c|c|c|c|}
\hline \multirow[b]{3}{*}{ Variable } & \multicolumn{6}{|c|}{ Pathway or Milestone } \\
\hline & \multicolumn{4}{|c|}{ Remediation } & \multicolumn{2}{|c|}{ College-Level Courses } \\
\hline & $\begin{array}{l}\text { Enrolled in } \\
\text { Remediation }\end{array}$ & $\begin{array}{l}\text { Enrolled in } \\
\text { Math } \\
\text { Remediation }\end{array}$ & $\begin{array}{l}\text { Enrolled in } \\
\text { Reading } \\
\text { Remediation }\end{array}$ & $\begin{array}{l}\text { Enrolled in } \\
\text { Writing } \\
\text { Remediation }\end{array}$ & $\begin{array}{l}\text { Passed First } \\
\text { College } \\
\text { Writing } \\
\text { Course }\end{array}$ & $\begin{array}{l}\text { Passed First } \\
\text { College Math } \\
\text { Course }\end{array}$ \\
\hline Older Student & $\begin{array}{c}1.073 \\
(0.086)\end{array}$ & $\begin{array}{r}1.054 \\
(0.078)\end{array}$ & $\begin{array}{c}1.255 \\
(0.063)^{*}\end{array}$ & $\begin{array}{c}1.243 \\
(0.062)^{*}\end{array}$ & $\begin{array}{c}1.519 \\
(0.339)\end{array}$ & $\begin{array}{c}2.007 \\
(0.153)^{*}\end{array}$ \\
\hline $\begin{array}{l}\text { Pathway or Milestone (Impact } \\
\text { for Younger Students) }\end{array}$ & $\begin{array}{c}0.575 \\
(0.018)^{*}\end{array}$ & $\begin{array}{c}0.592 \\
(0.019)^{*}\end{array}$ & $\begin{array}{c}0.686 \\
(0.025)^{*}\end{array}$ & $\begin{array}{c}0.657 \\
(0.023)^{*}\end{array}$ & $\begin{array}{c}2.566 \\
(0.239)^{*}\end{array}$ & $\begin{array}{c}4.698 \\
(0.207)^{*}\end{array}$ \\
\hline Interaction (Older * Milestone) & $\begin{array}{c}1.333 \\
(0.124)^{*}\end{array}$ & $\begin{array}{c}1.339 \\
(0.118)^{*}\end{array}$ & $\begin{array}{c}1.141 \\
(0.115)\end{array}$ & $\begin{array}{r}1.184 \\
(0.122)\end{array}$ & $\begin{array}{r}0.988 \\
(0.241)\end{array}$ & $\begin{array}{c}0.495 \\
(0.052)^{*}\end{array}$ \\
\hline $\begin{array}{l}\text { Pathway or Milestone Impact for } \\
\text { Older Students (Milestone * } \\
\text { Interaction) }\end{array}$ & 0.766 & 0.793 & 0.783 & 0.778 & 2.535 & 2.326 \\
\hline Deviance & 53780.52 & 53823.71 & 53980.25 & 53939.33 & - & - \\
\hline Change in Deviance $^{\dagger}$ & 304.80 & 261.61 & 105.07 & 145.99 & - & - \\
\hline
\end{tabular}

We note some additional interesting findings when this first general remediation variable is broken out into subject areas. The interaction term in row 3 of Table 5 is statistically significant only for mathematics remediation, and must be driving the statistical association for the general remediation result. The need to enroll in reading and writing developmental education courses did not seem to have different impacts on older and younger students, but age was a factor with math remediation. This finding highlights an important link between older students and the mathematics subject area. These students came to college with deficient or rusty math skills that were a key barrier to their success, and greater attention to their developmental mathematics paths was warranted. 
The last two milestones addressed in Table 5 pertain to students who enrolled in either math or writing developmental courses, respectively. For students enrolled in remedial writing, passing the first-year composition course more than doubled their odds of graduating. However, there does not seem to be any difference in impact between older and younger students. This is not the case for students who passed college algebra, the first college-level math course. Here we estimated that the odds ratio for older students is about half as strong as the ratio for younger students, although it is predicted to have a positive impact on graduation probabilities for all students. Thus, passing the first college-level math course could be much more important for younger students. This relationship is in line with our earlier findings regarding math remediation and older students. Figure 2 represents these results graphically. It is interesting to note the top two coincident hazard profiles, which show the probability of graduation for both older and younger remedial students who have passed college algebra. The gaps between the top line and the two lower lines are commensurate with the difference in the increase in probability of graduation for younger and older students who passed this course. 
Figure 2: Estimated Probability of Completion by Age and Passing First College-Level Math Class Subgroups

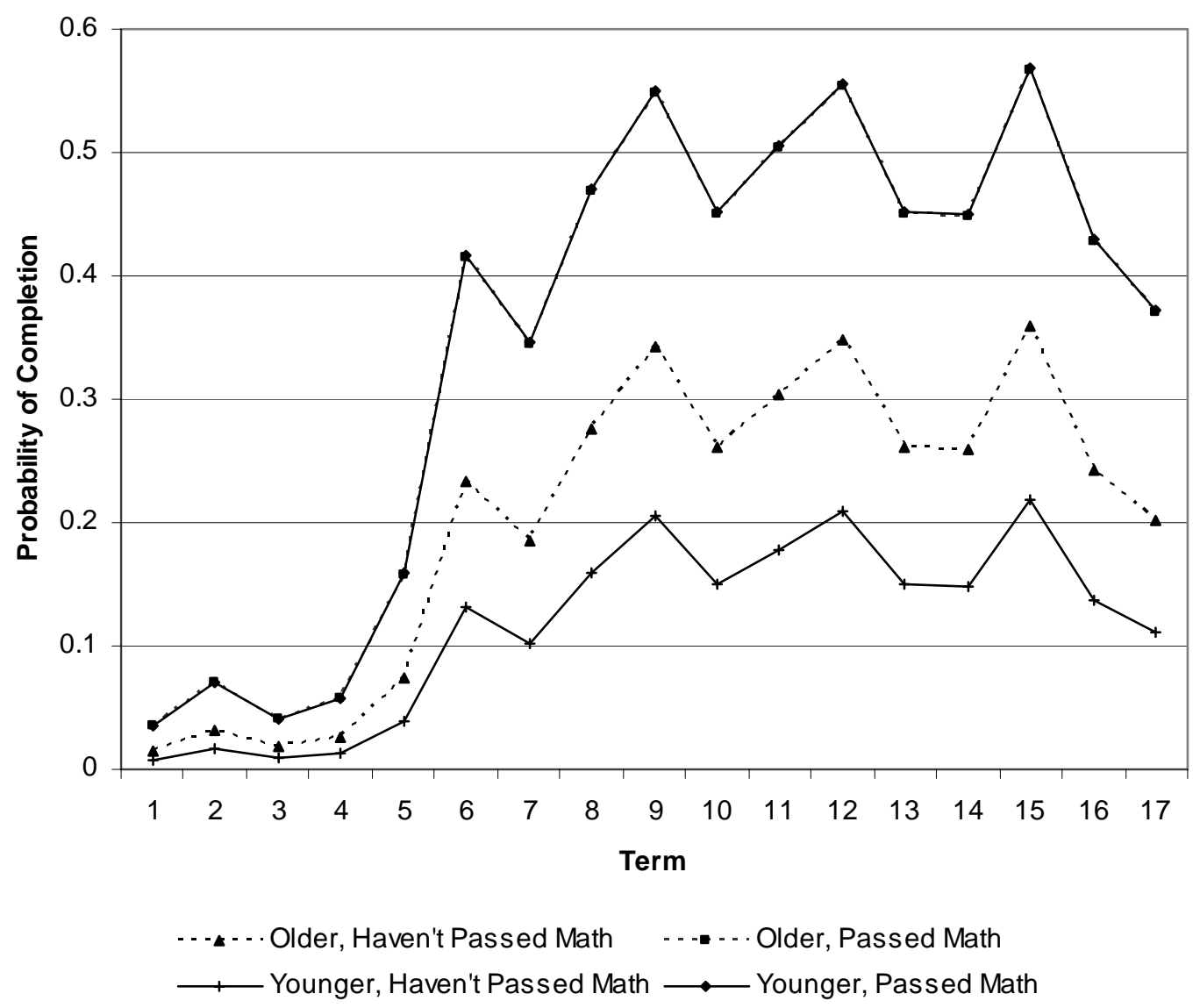

\section{Implications for Practice}

In this study we conducted an analysis that tests for differences in factors that affect community college completion by different student age groups. Using a single-risk discrete-time survival methodology, we found that younger and older students do in fact respond differently to reaching credit milestones, taking remedial courses, and passing college-level "gatekeeper” courses. Reaching milestones associated with credits earned or completing a portion of a program increases the probability of graduation for all students, but has a greater impact on younger students than on older ones. We also found that although enrollment in remediation 
decreases the odds of graduating in any given term, older students who enroll in remediation, and specifically mathematics remediation, are less negatively affected than are younger students who do the same. In addition to the above, this analysis produced the unexpected finding that after controlling for ability (as measured by math placement test scores), older students have a higher probability of graduating in any given trimester.

These findings have a number of implications for community college practice. First they support efforts to provide more intensive supports to students relatively early in their enrollment. Younger students in particular would benefit from orientations to college life, intensive advising and counseling, and other activities designed to engage them in the academic and social life of the college. This is the premise of the "first year in college experience" movement that grew out of a first-year seminar at the University of South Carolina in the early 1970s and has since spawned programs at numerous two- and four-year colleges across the country and a raft of publications and conferences focused on ensuring that incoming students are retained through the first year and return for the second (Barefoot et al., 2005; Upcraft et al., 2005).

One explanation for the finding that older students are less negatively affected by enrolling in remedial courses is that these students, having been out of school longer, may merely have basic skills that are "rusty" rather than seriously deficient. A second implication for practice of this study, therefore, is that colleges should consider offering "brush up" workshops or tutorials to older students who place into remedial courses but who do not have serious basic skills deficiencies in order to help them refresh their skills without having to enroll in semesterlong courses.

Third, because students who enroll in remedial courses are less likely to succeed, colleges should work with middle and high schools to help better prepare and motivate youth for 
postsecondary education before they enroll in college. Moreover, colleges should provide intensive supports to help remedial students, especially younger students, take and pass the initial-level college math courses, since passing these "gatekeepers" substantially increases the chances that students will succeed.

Finally, the finding that older students have a higher probability than younger students of graduating, after controlling for factors such as test scores and enrollment patterns, supports Bean and Metzner's (1985) model of nontraditional student attrition. The researchers posit that older students are more affected than traditional-age students by the need to balance work and family with school, and that these external pressures outweigh the effects of social integration. Our finding that older students do not benefit as much as younger students from attaining enrollment milestones provides further support for the applicability of Bean and Metzner's model to older community college students. It suggests that, in order to retain older students, colleges need help to mitigate the effects of the external pressures on them through flexible scheduling, evening and weekend courses, childcare, distance learning, and other means, rather than focus on providing the sorts of intensive advising, counseling, and other supports that are appropriate for younger students. Colleges should also consider offering accelerated programs and financial support to enable older students to attend full time and thus shorten the time it takes to reach the key milestones on the way to a degree and further education. 


\section{References}

Adelman, C. (1999). Answers in the tool box: Academic intensity, attendance patterns, and bachelor's degree attainment. Washington, DC: U.S. Department of Education, National Center for Education Statistics.

Adelman, C. (2004). Principal indicators of student academic histories in postsecondary education, 1972-2000. Washington, DC: U.S. Department of Education.

Adelman, C. (2005). Moving into town-and moving on. The community college in the lives of traditional-age students. Washington, DC: U.S. Department of Education.

Adelman, C. (2006). The toolbox revisited: Paths to degree completion from high school through college. Washington, DC: U.S. Department of Education.

Allison, P. (1984). Event history analysis: Regression for longitudinal event data. Thousand Oaks, CA: Sage.

Bailey, T., \& Alfonso, M. (2005). Paths to persistence: An analysis of research on program effectiveness at community colleges. Indianapolis: Lumina Foundation for Education.

Bailey, T., Leinbach, D., Scott, M., Alfonso, M., Kienzl, G., Kennedy, B., \& Marcotte, D. (2003). The characteristics of occupational sub-baccalaureate students entering the new millennium. New York: Columbia University, Teachers College, Community College Research Center.

Barefoot, B., Gardner, J., Cutright, M., Morris, L., Schroeder, C., et al. (2005). Achieving and sustaining institutional excellence for the first year of college. San Francisco: Jossey-Bass.

Bean, J. (1985). Interaction effects based on class level in an explanatory model of college student dropout syndrome. American Educational Research Journal, 22(1), 35-64.

Bean, J., \& Metzner, B. (1985). A conceptual model of nontraditional undergraduate student attrition. Review of Educational Research, 55(4), 485-540.

Cabrera, A., Burkum, K., \& La Nasa, S. (2005). Pathways to a four-year degree: Determinants of transfer and degree completion. In A. Seidman (Ed.), College student retention: A formula for student success (pp.155-214). Westport, CT: ACE/Praeger Series on Higher Education.

Cameron, S., \& Heckman, J. (1998). Life cycle schooling and dynamic selection bias: Models and evidence for five cohorts of American males. Journal of Political Economy, 106(2), 262333. 
Choy, S. (2002a). Nontraditional undergraduates: Findings from the condition of education, 2002. Washington, DC: U.S. Department of Education, National Center for Education Statistics.

Choy, S. (2002b). Access \& persistence: Findings from 10 years of longitudinal research on students. Washington, DC: American Council on Education.

Choy, S., \& Premo, M. (1995). Profile of older undergraduates, 1989-90. Washington, DC: U.S. Department of Education, National Center for Education Statistics.

Cohen, A., \& Brawer, F. (1996). The American community college ( $3^{\text {rd }}$ ed.). San Francisco: Jossey-Bass.

DesJardins, S. (2003). Event history methods: Conceptual issues and an application to student departure from college. In J. Smart (Ed.), Higher Education: Handbook of Theory and Research, 18, 421-471.

DesJardins, S., Ahlburg, D., \& McCall, B. (1999). An event history model of student departure. Economics of Education Review, 18 (3), 375-390.

Dolton, P., \& van der Klaauw, W. (1995). Leaving teaching in the UK: a duration analysis. Economic Journal, 105(2), 431-444.

Horn, L., \& Carroll, C. (1996). Nontraditional undergraduates: Trends in enrollment from 1986 to 1992 and persistence and attainment among 1989-90 beginning postsecondary students. Washington, DC: U.S. Department of Education, National Center for Education Statistics.

Ishitani, T. (2003). A longitudinal approach to assessing attrition behavior among firstgeneration students: Time-varying effects of pre-college characteristics. Research in Higher Education, 44(4), 433-449.

Jaccard, J. (2001). Interaction effects in logistic regression. Thousand Oaks, CA: Sage.

Jepsen, C. (2006, April). Basic skills in California's community colleges: Evidence from staff and self referrals. Paper presented at the 2006 Annual Meeting of the American Educational Research Association, San Francisco.

Johnson, I. (2006). Analysis of stopout behavior at a public research university: The multi-spell discrete-time approach. Research in Higher Education.

McCormick, A. (1999). Credit production and progress toward the bachelor's degree: An analysis of postsecondary transcripts for beginning students at 4-year institutions. Washington, DC: U.S. Department of Education, National Center for Education Statistics.

Pascarella, E., \& Terenzini, P. (2005). How college affects students: A third decade of research (Vol. 2). San Francisco, CA: Jossey-Bass. 
Rothstein, J. (2004). College performance predictions and the SAT. Journal of Econometrics, 121(1-2), 297-317.

Scott, M., \& Kennedy, B. (2005). Pitfalls in pathways: Some perspectives on competing risks event history analysis in education research. Journal of Educational and Behavioral Statistics, 30(4), 413-442.

Singer, J., \& Willett, J. (2003). Applied longitudinal data analysis: Modeling change and event occurrence. New York: Oxford University Press.

Tinto, V. (1993). Leaving college: Rethinking the causes and cures of student attrition. Chicago: University of Chicago Press.

U.S. Department of Education, National Center for Education Statistics. (2003). Integrated postsecondary education data system -Fall enrollment survey: 2002 (Data File).

Upcraft, M. L., Gardner, J. N., Barefoot, B., \& Associates. (2005.) Challenging and supporting the first-year student. San Francisco: Jossey-Bass. 